\title{
Karlovy Vary 2000
}

\author{
By Ron Holloway
}

Fall 2000 Issue of KINEMA

\section{5th KARLOVY VARY INTERNATIONAL FILM FESTIVAL}

The Brazilian film revival received another festival boost when Andrucha Waddington's Eu Tu Eles (Me You Them) scored a hardly unexpected Crystal Globe victory at the 35th Karlovy Vary festival (5-15 July 2000). Since 1995, when the new government (after the impeachment of the president) introduced friendly film laws to encourage investment in productions, a Golden Bear has been awarded at the Berlinale to Walter Salles's Central Station -- followed by an even more important commercial box-office hit: Carlos Diegues's Orfeu, a remake of Vinicius de Morales's play Orfeu de Carnival, the same source used by Marcel Camus for his Orfeu Negro (Black Orpheus), the Golden Palm winner at the 1959 Cannes festival. In June, a month before Karlovy Vary, Orfeu was the key film in the 24-film retrospective programmed at the Troia festival in Portugal to celebrate the discovery of Brazil 500 years ago by the explorer Cabral. As for Me You Them, this warm, discerning sex-comedy about a woman who lived together with three husbands (a true story drawn from life in the remote provinces) also won for Regina Case the Best Actress award and further critical recognition for talented screenwriter Elena Suares.

A film from Azerbaijan posed the strongest moral statement at Karlovy Vary: Yaver Rzayev's Sari Gyalan (Yellow Bride), presented in the "East of the West" section and awarded the Philip Morris Freedom Prize. Some five years in the making, with little chance of commercial release in Baku, Yellow Bride comes across as an honest, forthright statement on the absurdities of the recent Azeri-Armenian conflict and could be completed only with late-minute production assistance from the Rotterdam festival. Its title is drawn from a Caucasus folk legend in which the symbolic figure of a woman, a bride dressed in yellow, sacrifices herself for the sake of peace and unity among warring tribes. In Yellow Bride, set on a front between opposing villages, a bumbling chaplinesque Azeri refuses to execute an Armenian neighbour he knows and respects. Instead, they flee from the blood-thirsty carnage surrounding them -- in the company of a bride-in-yellow who has mysteriously survived the slaughter at her own wedding feast.

By an odd coincidence, the same theme was explored in reverse in an Iranian film selected for the competition: Khosto Sinai's Arous-E Atash (The Bride of Fire). Narrated in a conventional context reminiscent of postwar socialist-realist instructional films produced in Central Asian studios, it tells the story of a young woman from a village who is studying law at the university, falls in love with her teacher, and yet feels compelled to marry an uneducated cousin according to the traditions of her people. Should she refuse, she must then face the consequences of wrath, expulsion, and revenge -- depicted as a modern-day moral dilemma in Iran, and this at the close of the 20th century.

The same general theme of "love and revenge" in which a young woman obliges as both tribal pawn and sacrificial victim dominated Drahomíra Vihanová's Zpráva o putováni studentio Petra a Jakuba (The Pilgrimage of Students Peter and Jacob), a Czech-Slovak-French co-production in the competition. Reportedly five years in the making, this extended, repetitive, argumentative "Gypsy tale" is magnified via the conflicting testimony of two young, sensitive, inexperienced law students. When Peter and Jacob cannot agree on how a Gypsy friend should be judged for murdering the girl he loves, particularly after he has found her in the arms of another suitor, they turn first to the guardians of social conduct -- the courts and the church -- for answers. And thereafter, for years to come, they are doomed to embark upon a medieval-like "pilgrimage" -- a search into their own souls for a moral resolution to questions of guilt and justice, answers that can be found only in the unwritten laws of the Gypsy community itself.

Yet another pilgrimage into the depths of the soul characterizes Chang-Dong Lee's Peppermint Candy, the Korean competition entry that previously had opened the Pusan festival and was invited to the Directors Fortnight at Cannes. This stylistically arresting tale of lost innocence begins with a suicide that triggers a time-machine trip into the past to place the story in focus, each episode counting the strokes of fate that 
will inevitably turn a human being into a insensitive brute. Korean cinema has not only come of age; it's posing moral questions that interest and challenge us all.

One oddity in the Karlovy Vary competition attracted critical attention and was a definite crowd-pleaser: Jerzy Stuhr's Duze zwierze (The Big Animal, Poland). Apparently based on an idea found in the Krzysztof Kielowski legacy, The Big Animal is a camel left behind in a provincial town by a passing circus. When the friendly creature settles on the doorstep of a bank clerk, he immediately adopts the pet for his own, builds a shelter to house it, and then has to deal with all the "extras": registration, tax payment, the town council, to say nothing of the local photographer who smells a fortune to be earned with kid-and-camel photo-souvenirs. Although the tale wears thin as a feature film, it is kept going by the deadpan comic mime of actor-director Jerzy Stuhr -- and well deserved the runner-up Special Grand Prize and the Ecumenical Prize. It should be a winner too on the festival circuit.

\section{References}

\section{AWARDS}

\section{International Competition}

Karlovy Vary Crystal Globe (Grand Prix): Andrucha Waddington's Eu tu eles (Me You Them, Brazil)

Special Grand Jury Prize: Jerzy Stuhr's Duze zwierze (The Big Animal, Poland)

Special Jury Prize: Lee Chang-Dong's Bakha Satang (Peppermint Candy, South Korea)

Best Director: Vinko Bresan, Marshal (Marshal Tito's Spirit, Croatia)

Best Actress: Regina Case, Eu tu eles (Me You Them, Brazil)

Best Actor: Ian Hart, Aberdeen (Norway/UK), and Hamid Farokhnezad, Arous-E Atash (Bride of Fire, Iran)

\section{Documentary Competition}

Lars-Lennart Forsberg's Min mamma hade fjorton barn (My Mother Had Fourteen Children, Sweden, over 30 minutes)

Karin Wegsjö's Del av den värld som till hör dig (Part of the World That Belongs to You, Sweden, under 30 minutes)

\section{International Critics (FIPRESCI) Prize}

Fridrik Thor Fridriksson's Englar alheimsins (Angels of the Universe, Iceland-Norway-Sweden-GermanyDenmark)

Ecumenical Prize

Jerzy Stuhr's Duze zwierze (The Big Animal, Poland)

NETPAC Award

Competition: Lee Chang-Dong's Bakha Satnag (Peppermint Candy, South Korea)

Horizons: Edward Yang's Yi Yi (A One and a Two, Taiwan)

Don Quixote Award (International Federation of Film Clubs)

Lee Chang-Dong's Bakha Satnag (Peppermint Candy, South Korea)

Philip Morris Freedom Prize

East of the West Section: Yaver Rzayev's Sari gyalin (Yellow Bride, Russia)

Lifetime Achievement Awards

Carlos Saura (Spain) and Věra Chytilová (Czech Republic) 


\section{Author Information}

Ron HOLLOWAY (1933-2009) was an American critic, film historian, filmmaker and correspondent who adopted Europe as his home in the early fifties and spent much of his life in Berlin. He was an expert on the study of German cinema and against all odds produced, with his wife Dorothea, the journal German Film, keeping us up-to-date with the work of directors, producers and writers and the showing of German films around the world.

In 2007, Ron Holloway and his wife were awarded the Berlinale Camera Award. Ron also received the Bundesverdienstkreuz (German Cross of Merit), Polish Rings, Cannes Gold Medaille, the American Cinema Foundation Award, the Diploma for Support of Russian Cinema and an honorary award from the German Film Critics' Association.

Ron was also a valued contributor to Kinema for the past fifteen years. 